Chapter 7

\title{
What Are the Roles of National and International Institutions to Overcome Barriers in Diffusing Clean Energy Technologies in Asia?: Matching Barriers in Technology Diffusion with the Roles of Institutions
}

\author{
Masachika Suzuki \\ Additional information is available at the end of the chapter \\ http://dx.doi.org/10.5772/54124
}

\section{Introduction}

While the international negotiation on climate change does not make much progress in designing the post-Kyoto scheme, technology innovation and transfer is becoming a central issue in the negotiation. In Cancun in 2010, the parties agreed to organize the Technology Executive Committee (TEC) and the Climate Technology Centre and Network (CTCN) (UNFCCC 2011). The developed countries have committed to provide $\$ 100$ billion yearly to assist the developing countries in mitigation and adaptation through the Green Climate Fund (UNFCCC 2011). ${ }^{1}$ The scheme of the Fund is currently under discussion at the Transitional Committee for the design of the Green Climate Fund.

This paper consists of two parts. The first part of the paper attempts to show a broad landscape of barriers in technology diffusion in the developing countries by addressing two levels of barriers. The first level is about the barriers that are commonly observed among the developing countries (Section 2.1). The paper classifies these barriers into technological, financial and institutional barriers. The second level is about the barriers that are technology-specific (Section 2.2 and 2.3). Section 2.3 summaries the results of previous case studies that were

\footnotetext{
1 The text of the COP document states that [The Conference of the Parties] recognizes that developed country Parties commit, in the context of meaningful mitigation actions and transparency on implementation, to a goal of mobilizing jointly USD 100 billion per year by 2020 to address the needs of developing countries (paragraph 98); agrees that, in accordance with paragraph 1(e) of the Bali Action Plan, funds provided to developing country Parties may come from a wide variety of sources, public and private, bilateral and multilateral, including alternative sources (paragraph 99); and decides that a significant share of new multilateral funding for adaptation should flow through the Green Climate Fund (paragraph 100).
} 
conducted to uncover technology-specific barriers in diffusing clean energy technologies in Asia. These case studies include both technologies for industrial use such as wind, bio-energy and building energy efficiency and technologies for individual use such as LED (Light Emitting Diode) and Photovoltaic (PV) panels. It also contains technologies at the innovation stage such as Integrated Gasification Combined Cycle (IGCC) and Carbon Capture and Storage (CCS). Section 2.3 presents an analysis of the barriers through a comparison of the results of the case studies.

The second part of the paper explores roles of institutions to overcome identified barriers in diffusing clear energy technologies in Asia (Section 3). It addresses theoretical discussions on functions (or roles) of international and national institutions in technology innovation. It then attempts to match the barriers in technology diffusion identified in Section 2 with the functions of national and international institutions. The results of matching indicate that there are important roles of institutions both at the early and advanced stages of technological development to encourage R\&D cooperation from the public site (early stage) and enhance the enabling environment and facilitate finance for the technologies (advanced stage).

\section{Studies on barriers in technology diffusion in the developing countries}

Understanding barriers in technology diffusion lead to important lessons in designing policy instruments and institutions for diffusing clean energy technologies in the developing countries. With this understanding, researching about barriers has been part of the tasks under the UNFCCC as well as United Nations Environmental Program (UNEP) (UNFCCC 2011; UNEP Risø Centre on Energy, Climate and Sustainable Development 2011). Painuly indicates that there are several levels to explore and analyze such barriers. Painuly adds that the first level is a broad category of barriers and the lower levels include more detail and specific barriers (Painuly 2001). Section 2.1 illustrates barriers at the first level. Section 2.2 lists case studies that address barriers at a lower level that are more technology specific. Section 2.3 presents an analysis of the barriers through a comparison of the results of the case studies.

\subsection{Barriers commonly observed among the developing countries}

The barriers at the first level are the barriers that are commonly observed among the developing countries. There are substantial amounts of research projects that have attempted to identify the barriers at this level including Painuly (2001), OECD/IEA (2001), Painuly and Fenhann (2002) and Raddy and Painuly (2004). Table 1 summaries key barriers identified through these and other research. The barriers are classified into technological, financial and institutional barriers ${ }^{2,3}$ :

2 It is not possible to clearly distinguish barriers into the three classifications. Many barriers relate to more than two classifications. Under the circumstances, the paper attempts to fit each barrier into the most appropriate classification.

3Table 1 includes some technology-specific barriers as well as country/region-specific barriers. It is also noted that the table contains selected major barriers only. 


\begin{tabular}{|c|c|c|c|}
\hline Barriers & Barriers & Explanations & Source(s) \\
\hline \multirow[t]{28}{*}{ Technological } & Limited capacity to & - These technologies are primarily targeted at rural areas or poor & (Ravindranath and \\
\hline & assess, adopt, adapt & customers, who have limited capacity to absorb these technologies. & Balachandra 2009) \\
\hline & and absorb & There is a general resistance to change, which is magnified due to lack & (Painuly 2001) \\
\hline & technological options & of capacity to understand, adopt and adapt the technologies for & \\
\hline & & greater benefit. The capacity constrains are not only linked to its use & \\
\hline & & but in its production. There is limited manufacturing capacity and as a & \\
\hline & & result not much innovation has taken place. Scale-up of & \\
\hline & & manufacturing and therby reduction in the associated costs has not & \\
\hline & & taken place. (Ravindranath and Balachandra pp.1010) & \\
\hline & & - Technology not freely available in the market, technology developer & \\
\hline & & not willing to transfer technology, problems in import of technology/ & \\
\hline & & equipment due to restrictive policies/taxes etc. (Painuly pp.82) & \\
\hline & Lack of knowledge of & - Lack of knowledge of technology operation and management as & (Doukas et al 2009) \\
\hline & technology operation & well as limited availability of spare parts and maintenance expertise & (Luken and Rompaey \\
\hline & and management & (Doukas et al p.1139) & 2008) (OECD/IEA \\
\hline & & & 2001) \\
\hline & Lack of skilled & - This can be a constraint for producers (Painuly p.80) & (Painuly 2001) (Usha \\
\hline & personnel/training & - Lack of experts to train, lack of training facilities, inadequate efforts. & and Ravindranath \\
\hline & facilities & (Painuly pp.83) & 2002) (Jagadeesh \\
\hline & & - In China and much of South East Asia, there is a need for technically & 2000) (IPCC 2000) \\
\hline & & trained people and people with strong management skills. Where & (Guerin 2001) \\
\hline & & training of local workforce is provided, it should be recognized that & (Worrell et al. 2001) \\
\hline & & Asians tend to learn more effectively by coping, rather than as & (Flamos et al. 2008) \\
\hline & & individuals, when local language is used and with a practical "hands- & (OECD/IEA 2001) \\
\hline & & on" approach. Also the issue of training in intellectual property rights & \\
\hline & & is important. This is a long term issue but will be important for long & \\
\hline & & term changes in attitudes to intellectual property rights in China. & \\
\hline & & (Guerin pp.71) & \\
\hline \multirow[t]{11}{*}{ Technological } & Lack of standard and & - Product quality and product acceptability is affected. (Painuly pp.80) & (Painuly 2001) (Oliver \\
\hline & codes and certification & - Lack of institution/initiative to fix standards, lack of capacity, lack of & and Jackson 1999) \\
\hline & & facilities for testing/certification. (Painuly pp.83) & (IPCC 2000) (Joanna \\
\hline & & - A degree of standardization would improve the penetration of & 2007) (Jagadeesh \\
\hline & & photovoltaics (PVs), it would enable PVs to become more user & 2000) (OECD/IEA \\
\hline & & friendly. (Oliver and Jackson pp.381) & 2001) (Oltz and \\
\hline & & - Lack of standardization in system components resulting from the & Beerepoot 2010) \\
\hline & & wide range in design features and technical standards, and absence & \\
\hline & & of long-term policy instruments have resulted in manufacturing, & \\
\hline & & servicing and maintenance difficulties of wind turbines. (Jagadeesh & \\
\hline & & pp. 162) & \\
\hline \multirow[t]{3}{*}{ Financial } & Lack of access to & - High first costs and investments associated with mass & (Ravindranath and \\
\hline & financing & manufacturing remain as barriers. Both the users and the & Balachandra 2009) \\
\hline & & manufactures have very low capital. This problem is further & (Painuly 2001) \\
\hline
\end{tabular}




\begin{tabular}{|c|c|c|c|}
\hline \multirow[t]{20}{*}{ Barriers } & Barriers & Explanations & Source(s) \\
\hline & & accentuated by the rigid lending procedures that limited access to & (UNFCCC 2003) \\
\hline & & financing even when financing is available on standard norms. & (Worell et al. 2001) \\
\hline & & (Ravindranath and Balachandra pp.1010) & (Jagadeesh 2000) \\
\hline & & - Capital costs may go up due to increased risk perception. Adverse & (IPCC 2000)(Thorne \\
\hline & & effect on competition and efficiency. (Painuly pp.79) & 2008) \\
\hline & & - Small and medium scale enterprises (SMEs) above all lack the & \\
\hline & & finances for cleaner technologies, but also contact with larger & \\
\hline & & technology manufacturers and formal information channels. (UNFCCC & \\
\hline & & 2003, p.12) & \\
\hline & & - Limited capital availability will lead to high hurdle rates for energy & \\
\hline & & efficiency investments because capital is used for competing & \\
\hline & & investment priorities... High inflation rates in developing countries and & \\
\hline & & CEITs, lack of suffcient infrastructure increase the risks for domestic & \\
\hline & & and foreign investors and limit the availability of capital (Worrell et al & \\
\hline & & 2001, pp.6-7) & \\
\hline & & - International public finance is no longer going into energy & \\
\hline & & (electricity) infrastructure, which is now seen as of interest to the & \\
\hline & & private sector under the neo-liberal or privatization agenda (Thorne, & \\
\hline & & p.3) & \\
\hline \multirow[t]{13}{*}{ Financial } & Potential lack of & - In general, technology imported from industrialized countries is & (Karakosta et al, \\
\hline & commercial viability & more efficient but also more expensive than technology & 2010) \\
\hline & & manufactured locally, and it therefore requires higher initial & \\
\hline & & investment costs. This is of particular importance for the transfer of & \\
\hline & & environmentally sound technologies. Furthermore, as a result of their & \\
\hline & & typically early commercialization stage, environmentally sound & \\
\hline & & technologies are often considered riskier than existing commercial & \\
\hline & & technologies (Karakosta et al., p.1551) & \\
\hline & Lack of financial & - Adverse effect on competition and efficiency. (Painuly pp.79) & (Painuly 2001) \\
\hline & institutions to support & - Under-developed capital markets, restricted entry to capital markets, & (Jagadeesh 2000) \\
\hline & renewable energy & instruments unfavorable regulations. (Painuly pp.83) & \\
\hline & technologies, lack of & & \\
\hline & instruments & & \\
\hline \multirow[t]{10}{*}{ Institutional } & Uncertain & - Many of the renewable energy technologies in India are still in the & (Redd and Painuly \\
\hline & governmental policies & development stage. There are no sufficient governmental & 2004) (Painuly 2001) \\
\hline & & regulations/ incentives to stimulate the adoption of renewable & (Worell et al. 2001) \\
\hline & & energy technologies by business and industries. They include: (a) lack & (Schneider and \\
\hline & & of explicit national policy for renewable energy at end-use level; (b) & Hoffman 2008) \\
\hline & & incomplete transition to cost-based electric tariffs for most residential & (Doukas et al. 2009) \\
\hline & & and some industrial customers; (c) poor availability of credit to the & (Karakosta et al. \\
\hline & & purchase of renewable energy technologies in the economy; and (d) & 2010) (OECD/IEA \\
\hline & & lack of application of modern management skills in energy & 2001) \\
\hline & & development agencies. (Reddy and Painuly pp.1436) & \\
\hline
\end{tabular}




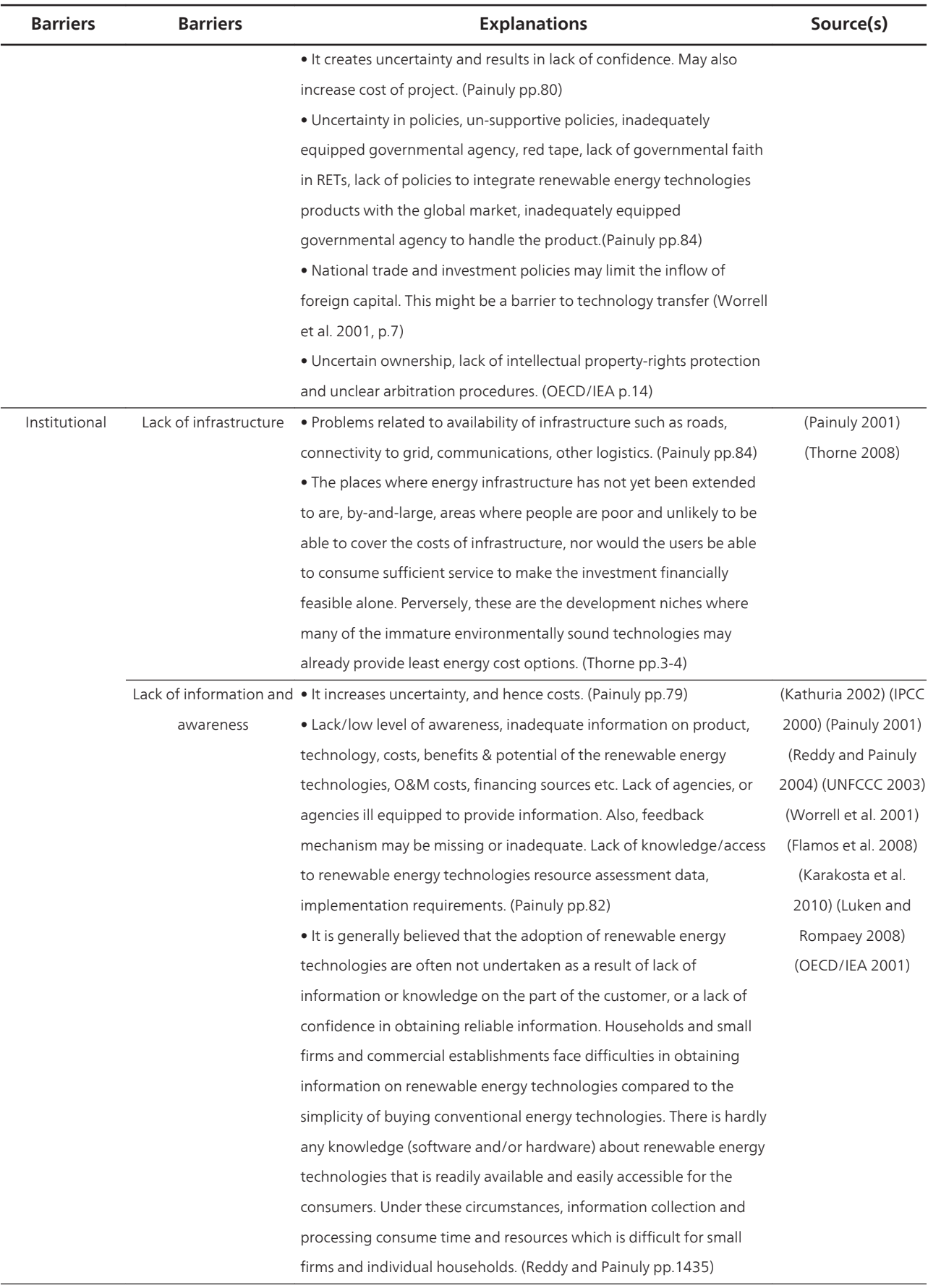




\begin{tabular}{|c|c|c|c|}
\hline Barriers & Barriers & Explanations & Source(s) \\
\hline Institutional & $\begin{array}{c}\text { Lack of consumer } \\
\text { acceptance }\end{array}$ & $\begin{array}{l}\text { - Adoption of renewable energy technologies are generally } \\
\text { influenced by consumer perceptions of the quality and usefulness of } \\
\text { these items when compared to conventional technologies. } \\
\text { Renewable energy technologies are often perceived to be used with } \\
\text { discomfort or sacrifice rather than as providing equivalent services } \\
\text { with less energy and cost. Also, while purchasing a technology, } \\
\text { consumers take the advice of their friends rather than obtaining } \\
\text { information from the experts and take decisions which may not be } \\
\text { economically rationale. (Reddy and Painuly pp.1436-1437) } \\
\text { - Unknown product, aesthetic considerations, products lacks appeal, } \\
\text { resistance to change, cultural reasons, high discount rates of } \\
\text { consumers, inadequate information. (Painuly pp.84) } \\
\text { - Many potential users of sustainable energy technologies have no or } \\
\text { little experience with their application and the assistance provided in } \\
\text { the development of such technologies is insufficient. Moreover, } \\
\text { dissemination of EU experience sustainable energy technology } \\
\text { implementation to other countries in the world has been limited } \\
\text { (Flamos, p.5) }\end{array}$ & $\begin{array}{l}\text { (Reddy and Painuly } \\
\text { 2004) (Painuly 2001) } \\
\text { (Flamos et al. 2008) }\end{array}$ \\
\hline
\end{tabular}

Table 1. Barriers (technological, financial and institutional) observed among the developing countries

Technological barriers include not only limited access to the international technology market but also limited capacity to assess, adopt, adapt and absorb technological options (Ravindranath and Balachandra 2009; Painuly 2001). As the table indicates, lack of knowledge of technology operation and management as well as lack of skilled personnel/training facilities can be a major barrier for successful diffusion of clean energy technologies (Doukas et al. 2009; Luken and Rompaey 2008; Painuly 2001; Usha and Ravindranath 2002; Jagadeesh 2000; IPCC 2000; Guerin 2001; Worrell et al. 2001; Flamos et al. 2008; OECD and IEA 2001). Lack of standard and codes and certification can be a barrier too since product quality and product acceptability is affected (Painuly 2001).

A lack of financing is a major part of the financial barriers (Ravindranath and Balachandra 2009; Painuly 2001; UNFCCC 2003; Worell et al. 2001; Jagadeesh 2000; IPCC 2000; Thorne 2008). Ravindranath and Balachandra (2009) states that "high first costs and investments associated with mass manufacturing remain as barriers. Both the users and the manufactures have very low capital. This problem is further accentuated by the rigid lending procedures that limited access to financing even when financing is available on standard norms." At this point, Karakosta et al. (2010) further elaborates that "in general, technology imported from industrialized countries is more efficient but also more expensive than technology manufactured locally, and it therefore requires higher initial investment costs. This is of particular importance for the transfer of environmentally sound technologies." Lack of financial institutions to support renewable energy technologies as well as lack of financial instruments is also highlighted as part of the financial barriers (Painuly 2001; Jagadeesh 2000). 
Institutional barriers include lack of explicit forms of institutions such as goals, policies, regulations and incentive programs as well as lack of implicit form of institutions such as information, awareness, social acceptance, and conditions of the surrounding environment. As for explicit forms of institutions, Painuly (2001) points out uncertainty in policies, unsupportive policies, inadequately equipped governmental agency, red tape, lack of governmental faith in renewable energy technologies, lack of policies to integrate renewable energy technologies products with the global market, inadequately equipped governmental agency to handle the product. Lack of infrastructure is another aspect of institutional barriers, pointed out by Painuly (2001), that is, problems related to availability of infrastructure such as roads, connectivity to grid, communications, and other logistics. As for implicit form of institutions, Painuly (2001) points out lack/low level of awareness, inadequate information on product, technology, costs, benefits and potential of the renewable energy technologies, O\&M costs, financing sources. Flamos et al. (2008) addresses lack of customer acceptance as an institutional barrier. It points out that "many potential users of sustainable energy technologies have no or little experience with their application and the assistance provided in the development of such technologies is insufficient" (Flamos et al. 2008).

Section 2.1 addressed barriers that are commonly observed among the developing countries. Section 2.2 illustrates case studies addressing technology-specific barriers.

\subsection{Case studies addressing technology-specific barriers}

There are a number of research initiatives that have attempted to identify barriers through the case study approach. The advantage of the case study approach is that it helps to uncover technology-specific barriers, while other studies looking at the developing countries or clean energy as a whole may overlook these barriers. Table 2 lists the case studies that are reviewed in this paper":

\begin{tabular}{|c|c|c|c|c|}
\hline & \multirow[t]{2}{*}{ Research organization/individuals } & \multicolumn{2}{|c|}{$\begin{array}{l}\text { Information on each case } \\
\text { study }\end{array}$} & \multirow[t]{2}{*}{ Sources } \\
\hline & & Country & Technology & \\
\hline Case study 1 & $\begin{array}{l}\text { SPRU (Science and Technology Policy } \\
\text { Research) at University of Sussex and } \\
\text { TERI in India }\end{array}$ & India & Wind power & $\begin{array}{l}\text { Ockwell, D., J. Watson et al. } \\
\qquad(2009)\end{array}$ \\
\hline Case study 2 & $\begin{array}{l}\text { SPRU at University of Sussex and TERI in } \\
\text { India }\end{array}$ & India & $\begin{array}{l}\text { Integrated } \\
\text { Gasification } \\
\text { Combined } \\
\text { Cycle } \\
\text { (IGCC) }\end{array}$ & $\begin{array}{l}\text { A: Ockwell, D., J. Watson et al. } \\
\qquad \begin{array}{r}(2007) \\
\text { B: Ockwell, D., J. Watson et al. } \\
(2009)\end{array}\end{array}$ \\
\hline
\end{tabular}

4 This paper looks into key case studies in Asia only, although there are case studies being conducted in other parts including South America and Africa. 


\begin{tabular}{|c|c|c|c|c|}
\hline & \multirow[t]{2}{*}{ Research organization/individuals } & \multicolumn{2}{|c|}{$\begin{array}{l}\text { Information on each case } \\
\text { study }\end{array}$} & \multirow[t]{2}{*}{ Sources } \\
\hline & & Country & Technology & \\
\hline Case study 3 & $\begin{array}{l}\text { SPRU at University of Sussex and TERI in } \\
\text { India }\end{array}$ & India & $\begin{array}{l}\text { LED (Light } \\
\text { Emitting } \\
\text { Diode) }\end{array}$ & $\begin{array}{l}\text { Ockwell, D., J. Watson et al. } \\
\qquad(2007)\end{array}$ \\
\hline Case study 4 & $\begin{array}{l}\text { SPRU at University of Sussex and TERI in } \\
\text { India }\end{array}$ & India & Biomass & $\begin{array}{l}\text { Ockwell, D., J. Watson et al. } \\
\qquad(2007)\end{array}$ \\
\hline Case study 5 & $\begin{array}{l}\text { SPRU at University of Sussex and TERI in } \\
\text { India }\end{array}$ & India & $\begin{array}{l}\text { Hybrid } \\
\text { vehicles }\end{array}$ & $\begin{array}{l}\text { A: Ockwell, D., J. Watson et al. } \\
\qquad \begin{array}{r}(2007) \\
\text { B: Ockwell, D., J. Watson et al. } \\
\text { (2009) }\end{array}\end{array}$ \\
\hline Case study 6 & $\begin{array}{l}\text { SPRU at University of Sussex and TERI in } \\
\text { India }\end{array}$ & India & $\begin{array}{l}\text { Photovoltaic } \\
\text { (PV) panels }\end{array}$ & $\begin{array}{l}\text { Ockwell, D., J. Watson et al. } \\
\qquad(2009)\end{array}$ \\
\hline Case study 7 & $\begin{array}{l}\text { International Institute for Industrial } \\
\text { Environmental Economics (IIIEE) at } \\
\text { Lund University }\end{array}$ & $\begin{array}{l}\text { Developing } \\
\text { countries }\end{array}$ & $\begin{array}{c}\text { Carbon } \\
\text { Capture } \\
\text { and Storage } \\
\text { (CCS) }\end{array}$ & Dalhammar, C. et al. (2009) \\
\hline Case study 8 & IIIEE at Lund University & $\begin{array}{l}\text { Developing } \\
\text { countries }\end{array}$ & $\begin{array}{l}\text { Building } \\
\text { energy } \\
\text { Efficiency }\end{array}$ & Dalhammar, C. et al. (2009) \\
\hline Case study 9 & $\begin{array}{c}\text { United Nations Department of } \\
\text { Economic and Social Affairs (DESA) }\end{array}$ & China & Wind power & United Nations, DESA \\
\hline $\begin{array}{l}\text { Case study } \\
10\end{array}$ & Lewis J. & $\begin{array}{l}\text { India and } \\
\text { China }\end{array}$ & Wind power & $\begin{array}{l}\text { A:Lewis, J., (2007a) } \\
\text { B:Lewis, J., (2007b) }\end{array}$ \\
\hline $\begin{array}{l}\text { Case study } \\
11\end{array}$ & $\begin{array}{l}\text { Mizuno E. (on a publication by UNEP } \\
\text { Risø Centre on Energy, Climate and } \\
\text { Sustainable Development) }\end{array}$ & India & Wind power & Mizuno. (2011) \\
\hline $\begin{array}{l}\text { Case study } \\
12\end{array}$ & $\begin{array}{l}\text { (Ravindranath and Rao on a publication } \\
\text { by UNEP Risø Centre on Energy, Climate } \\
\text { and Sustainable Development) }\end{array}$ & India & Bioenergy & Ravindranath and Rao (2011) \\
\hline $\begin{array}{c}\text { Case study } \\
13\end{array}$ & Suzuki, M., Okazaki B., and Jain K. & Thailand & Biogas & $\begin{array}{l}\text { A: Suzuki, M., Okazaki B., and } \\
\text { Jain K. (2010) } \\
\text { B: Jain K., Okazaki B., Suzuki, M. } \\
\text { (2011) }\end{array}$ \\
\hline
\end{tabular}

Table 2. List of case studies reviewed in this paper

The Science and Technology Policy Research (SPRU) at University of Sussex and TERI in India jointly conducted a research project looking into barriers through several case studies in India including wind power, IGCC (Integrated Gasification Combined Cycle), LED (Light Emitting 
Diode), biomass, hybrid vehicles and photovoltaic (PV) panels (Case Study 1-6) (Ockwell, D., J. Watson et al. 2007; Ockwell, D., J. Watson et al. 2009). This is the most comprehensive research project thus far looking into barriers through the case study approach. The IIIEE at Lund University in Sweden conducted several case studies including Carbon Capture and Storage (CCS) and building energy efficiency (Case Study 7 and 8) (Dalhammar, C. et al. 2009). In addition, there are a number of case studies that are conducted on the individual basis (Case Study 9-13).

It is observed that many of these case studies are conducted in China and India. This is probably relating to the fact that these two countries have the largest potentials in diffusing clean energy technologies among the developing countries. Another point to note among these case studies is that two popular targets for a case study are wind power and bio-energy (including biomass/ biogas). This is possibly due to the fact that these two technologies are at the stage where they are successfully implemented in some cases but there are still facing barriers to point out for further diffusion. On the other hand, Table 2 also indicates that there are a variety of research interests with respect to the targeted technologies for analysis. Some research interests are geared toward to the technologies at the innovation stage such as IGCC and CCS. Some research interests are directed to the products for individual use rather than industrial use such as hybrid vehicles, LEDs, and PV. The diversity in the targeted technologies for analysis may lead to interesting finding about barriers.

\subsection{Comparative study on technology-specific barriers}

Section 2.3 compares the results of the case studies identified in Section 2.2. Table 3 summarizes the results of the studies:

\begin{tabular}{|c|c|c|c|c|c|c|}
\hline \multirow{2}{*}{\multicolumn{2}{|c|}{$\begin{array}{c}\text { Research } \\
\text { organizations/ } \\
\text { individuals }\end{array}$}} & \multicolumn{2}{|c|}{ Information on case study } & \multicolumn{3}{|c|}{ Barriers } \\
\hline & & Country & Technology & Technological barriers & Financial barriers & Institutional barriers \\
\hline $\begin{array}{l}\text { Case } \\
\text { study } 1\end{array}$ & $\begin{array}{l}\text { SPRU (Science } \\
\text { and Technology } \\
\text { Policy Research) } \\
\text { at University of } \\
\text { Sussex and TERI } \\
\text { in India }\end{array}$ & India & Wind power & & & $\begin{array}{l}\text {-IPR is the main issue. The } \\
\text { transfer of technological know- } \\
\text { how to Indian companies was } \\
\text { restricted. (p.116) } \\
\text { - The high cost of IPR } \\
\text { acquisition. (p.118) } \\
\text { - In the joint ventures and } \\
\text { collaborative ventures, it had } \\
\text { been noticed that the [Indian] } \\
\text { companies had to depend on } \\
\text { their European counterparts } \\
\text { for all technical aspects and } \\
\text { even operation and } \\
\text { maintenance issues. (p.117) }\end{array}$ \\
\hline
\end{tabular}




\begin{tabular}{|c|c|c|c|c|c|c|}
\hline \multirow{3}{*}{ 更 } & \multirow{3}{*}{$\begin{array}{c}\text { Research } \\
\text { organizations/ } \\
\text { individuals }\end{array}$} & \multicolumn{2}{|c|}{ Information on case study } & \multicolumn{3}{|c|}{ Barriers } \\
\hline & & Country & Technology & Technological barriers & Financial barriers & Institutional barriers \\
\hline & & & & & & $\begin{array}{l}\text { - It is very important to } \\
\text { develop the indigenous } \\
\text { capacity for technology } \\
\text { development and } \\
\text { manufacturing. Equally } \\
\text { important would be to } \\
\text { incentivize innovations from } \\
\text { the viewpoint of national } \\
\text { priority. (p.120) }\end{array}$ \\
\hline $\begin{array}{l}\text { Case } \\
\text { study } 2\end{array}$ & $\begin{array}{l}\text { SPRU (Science } \\
\text { and Technology } \\
\text { Policy Research) } \\
\text { at University of } \\
\text { Sussex and TERI } \\
\text { in India }\end{array}$ & India & $\begin{array}{l}\text { IGCC } \\
\text { (Integrated } \\
\text { Gasification } \\
\text { Combined } \\
\text { Cycle) }\end{array}$ & $\begin{array}{l}\text { - Limited amount of } \\
\text { testing of IGCC that has } \\
\text { been done with Indian } \\
\text { grade coal. All IGCC } \\
\text { demonstration plants to } \\
\text { date have been based on } \\
\text { coals with different } \\
\text { characteristics to Indian } \\
\text { coal, especially ash } \\
\text { content and ash fusion } \\
\text { temperature.(A:p.58) } \\
\text { - The long-term success } \\
\text { of technology transfer in } \\
\text { technologies such as } \\
\text { gasification relies on } \\
\text { building technological } \\
\text { capacity within recipient } \\
\text { countries. (A:p.58) }\end{array}$ & $\begin{array}{l}\text { - The two key risks } \\
\text { associated with IGCC } \\
\text { are high capital costs } \\
\text { and the lack of } \\
\text { reliable operational } \\
\text { history. The risks } \\
\text { associated with high } \\
\text { capital cost are } \\
\text { amplified by the } \\
\text { limited operational } \\
\text { history and the new } \\
\text { nature of this } \\
\text { particular application } \\
\text { of gasification. (A:p. } \\
\text { 58) }\end{array}$ & $\begin{array}{l}\text { - Premature to comment on } \\
\text { IPR issues related to IGCC, since } \\
\text { this technology is not } \\
\text { considered to be commercial } \\
\text { globally. (B:p.110) }\end{array}$ \\
\hline $\begin{array}{l}\text { Case } \\
\text { study } 3\end{array}$ & $\begin{array}{l}\text { SPRU (Science } \\
\text { and Technology } \\
\text { Policy Research) } \\
\text { at University of } \\
\text { Sussex and TERI } \\
\text { in India }\end{array}$ & India & $\begin{array}{l}\text { LED (Light } \\
\text { Emitting } \\
\text { Diode) }\end{array}$ & $\begin{array}{l}\text { - Although the technical } \\
\text { competency in India } \\
\text { exists in the fields of } \\
\text { material science, } \\
\text { engineering, control } \\
\text { electronics and other } \\
\text { relevant fields, they have } \\
\text { to be nurtured in the } \\
\text { context of LED } \\
\text { technology.(p.72) } \\
\text { - Indigenous capacity is } \\
\text { to be developed quickly }\end{array}$ & $\begin{array}{l}\text { - No clear indication } \\
\text { about the type of } \\
\text { market that exists for } \\
\text { LED. (p.69) } \\
\text { - The leading players } \\
\text { worldwide are not } \\
\text { considering India as a } \\
\text { potential region for } \\
\text { investment as they do } \\
\text { not see any market in } \\
\text { India at present. (p. } \\
\text { 72) }\end{array}$ & $\begin{array}{l}\text { - It is a highly protected } \\
\text { technology. As there are } \\
\text { various processes involved in } \\
\text { manufacturing LED chips, each } \\
\text { process is patented and } \\
\text { requires huge investment. At } \\
\text { present the cost of investing in } \\
\text { both chip manufacturing and } \\
\text { resolving the IPR issues is } \\
\text { substantially high compared to } \\
\text { importing the chips. Therefore } \\
\text { in India, the chips are imported }\end{array}$ \\
\hline
\end{tabular}




\begin{tabular}{|c|c|c|c|c|c|c|}
\hline \multirow{2}{*}{\multicolumn{2}{|c|}{$\begin{array}{c}\text { Research } \\
\text { organizations/ } \\
\text { individuals }\end{array}$}} & \multicolumn{2}{|c|}{ Information on case study } & \multicolumn{3}{|c|}{ Barriers } \\
\hline & & Country & Technology & Technological barriers & Financial barriers & Institutional barriers \\
\hline & & & & $\begin{array}{l}\text { so that when technology } \\
\text { is transferred it can be } \\
\text { taken up. (p.74) }\end{array}$ & $\begin{array}{l}\text { - Import of LED is } \\
\text { much easier and } \\
\text { cheaper than to } \\
\text { manufacture it } \\
\text { because of IPR issues. } \\
\text { (p.69) } \\
\text { - LED chip } \\
\text { manufacturing } \\
\text { requires several } \\
\text { processes. Each } \\
\text { process involves } \\
\text { energy as well as } \\
\text { capital-intensive } \\
\text { equipment. The } \\
\text { existing players in } \\
\text { India are relatively } \\
\text { smaller in size and are } \\
\text { not ready/capable of } \\
\text { investing huge } \\
\text { amounts for LED chip } \\
\text { manufacturing. (p.72) }\end{array}$ & $\begin{array}{l}\text { primarily from China, Taiwan, } \\
\text { Japan, the US and other } \\
\text { countries. (p.72) }\end{array}$ \\
\hline $\begin{array}{l}\text { Case } \\
\text { study } 4\end{array}$ & $\begin{array}{l}\text { SPRU (Science } \\
\text { and Technology } \\
\text { Policy Research) } \\
\text { at University of } \\
\text { Sussex and TERI } \\
\text { in India }\end{array}$ & India & Biomass & $\begin{array}{l}\text { - The opportunity cost of } \\
\text { power outages at } \\
\text { briquetting plants. In } \\
\text { many regions of India, } \\
\text { electricity from the grid } \\
\text { cuts out for hours at a } \\
\text { time. (p.80) } \\
\text { - The lack of accessibility } \\
\text { to power presents } \\
\text { problems. In India, where } \\
\text { electricity connections } \\
\text { are often unavailable in } \\
\text { rural locales, the power } \\
\text { requirement for } \\
\text { briquetting machines } \\
\text { could prove to be a major } \\
\text { barrier to establishing } \\
\text { plants in remote areas } \\
\text { even if they are rich in }\end{array}$ & $\begin{array}{l}\text { - Entrepreneurs and } \\
\text { manufacturers alike } \\
\text { identified working } \\
\text { capital as a primary } \\
\text { barrier to successful } \\
\text { commercialization of } \\
\text { briquettes. (p.79) } \\
\text { - Banks are reluctant } \\
\text { to finance agro } \\
\text { residue projects. } \\
\text { These products have } \\
\text { traditionally been } \\
\text { viewed as waste, with } \\
\text { no collateral value. (p. } \\
\text { 79) } \\
\text { - Because of the low } \\
\text { repayment record, } \\
\text { briquetting has } \\
\text { developed a poor }\end{array}$ & $\begin{array}{l}\text { - As long as ram and die } \\
\text { machines were selling and } \\
\text { operating at an acceptable } \\
\text { level, manufacturers were not } \\
\text { willing to begin a new } \\
\text { endeavor that carried with it } \\
\text { some measure of uncertainty. } \\
\text { (p.77) } \\
\text { - The raw material situation is } \\
\text { quite different in India, where } \\
\text { sawdust is a commodity rather } \\
\text { than a waste product and is in } \\
\text { fact widely used, unprocessed, } \\
\text { as a cooking fuel. (p.78) } \\
\text { - The statistics about India's } \\
\text { vast biomass resources and } \\
\text { statements about the "virtually } \\
\text { unlimited" supply of biomass in } \\
\text { India can be }\end{array}$ \\
\hline
\end{tabular}




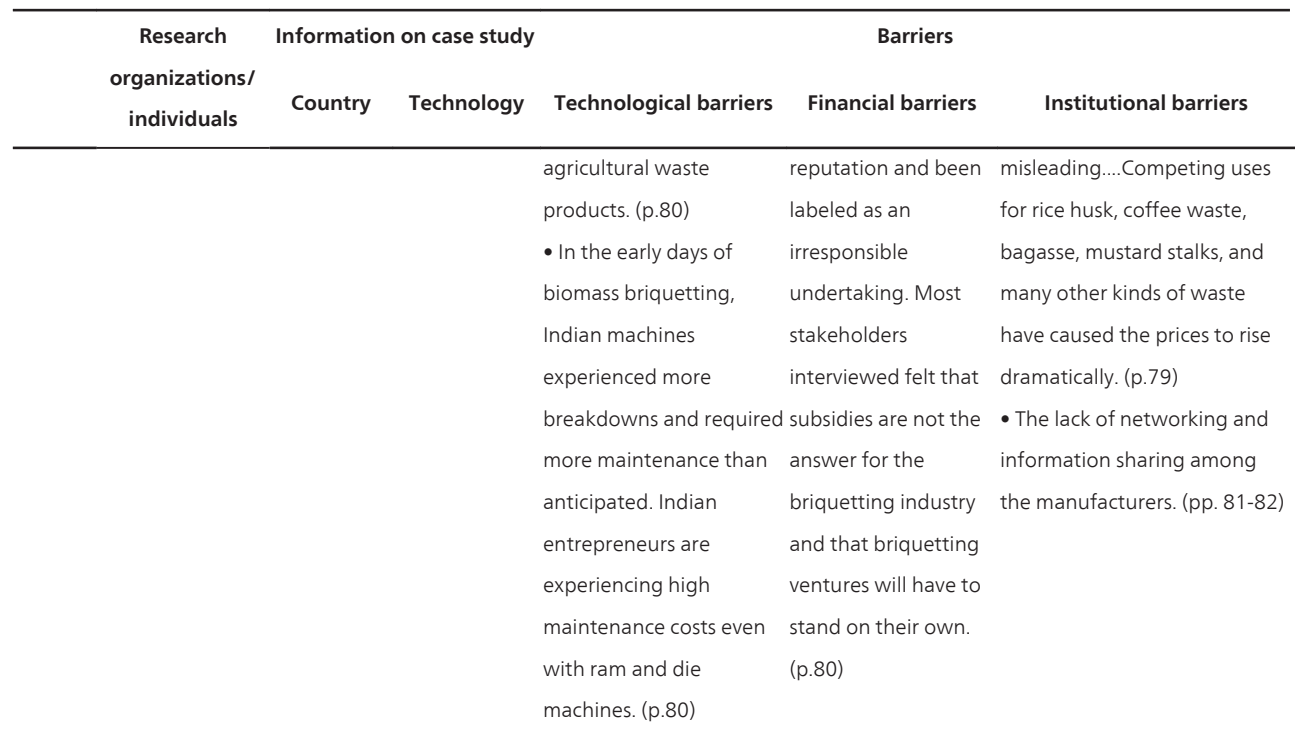

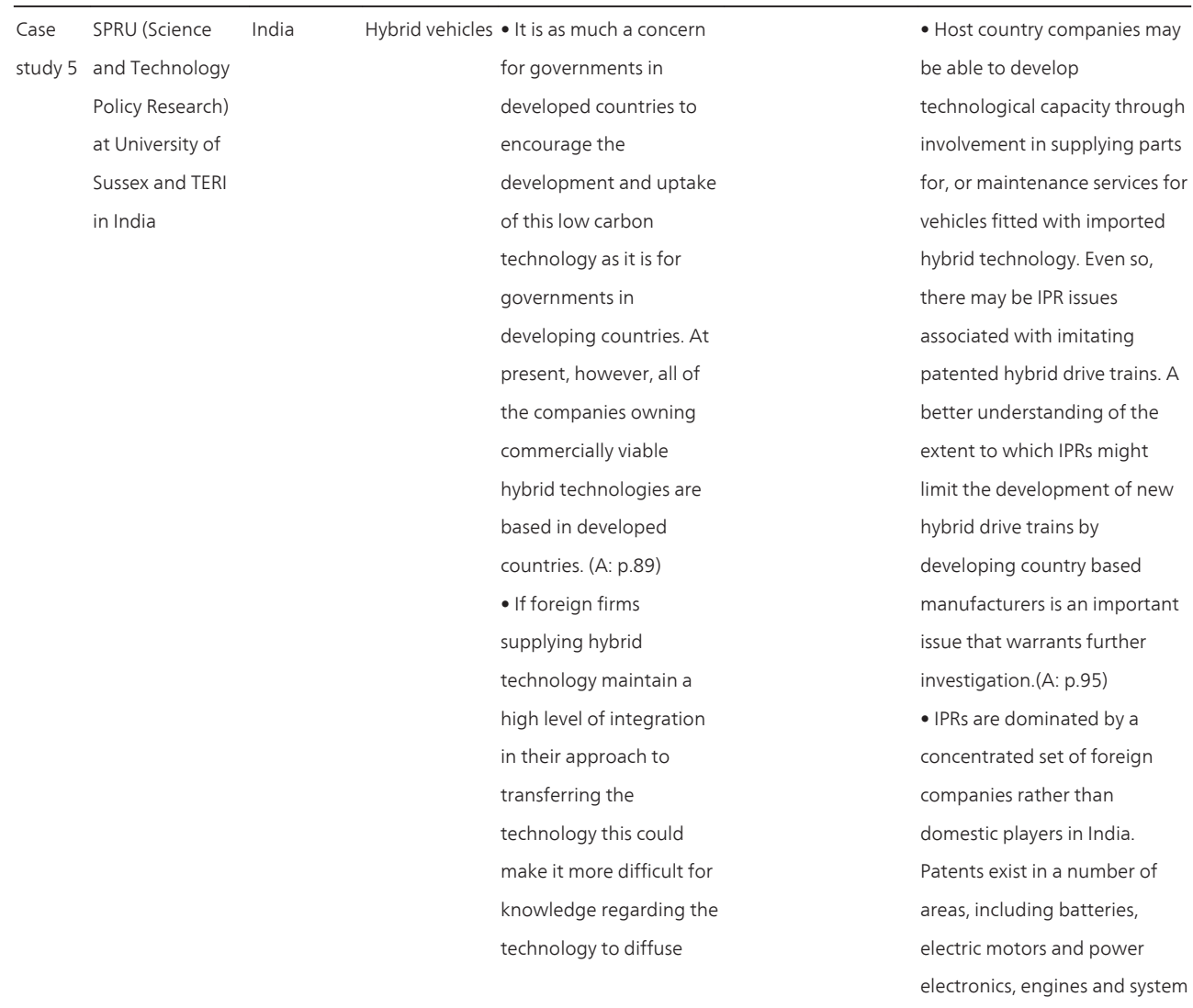




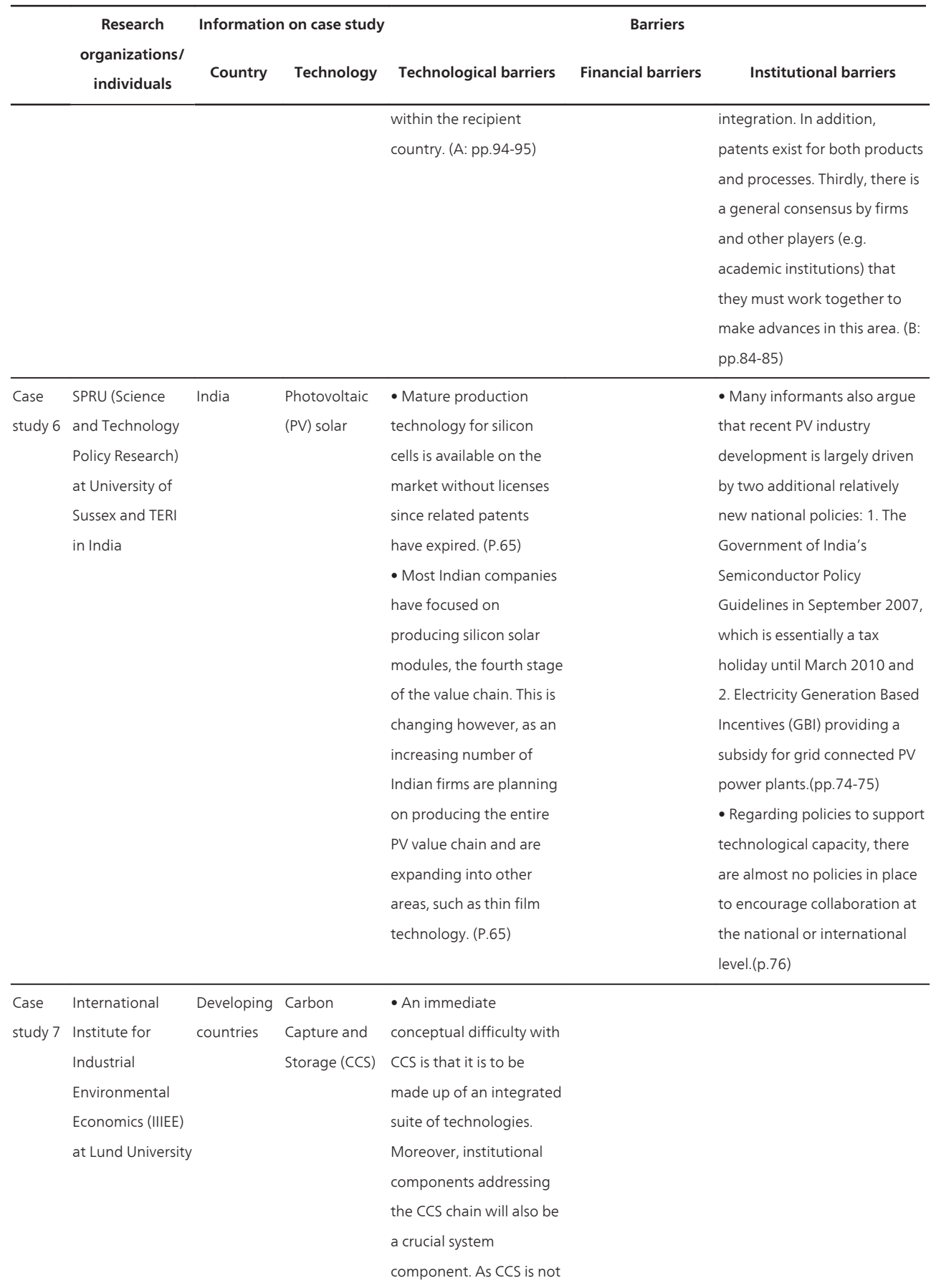




\begin{tabular}{|c|c|c|c|c|c|c|}
\hline \multirow{3}{*}{. } & \multirow{3}{*}{$\begin{array}{c}\text { Research } \\
\text { organizations/ } \\
\text { individuals }\end{array}$} & \multicolumn{2}{|c|}{ Information on case study } & \multicolumn{3}{|c|}{ Barriers } \\
\hline & & Country & Technology & Technological barriers & Financial barriers & Institutional barriers \\
\hline & & & & $\begin{array}{l}\text { market mature and does } \\
\text { not have any commercial } \\
\text { examples in operation, } \\
\text { this report cannot } \\
\text { address CCS system } \\
\text { transfer. Rather, one } \\
\text { example of an incipient } \\
\text { technology transfer } \\
\text { framework is noted here } \\
\text { there are two transfer } \\
\text { projects within its remit. } \\
\text { (p.69) }\end{array}$ & & \\
\hline $\begin{array}{l}\text { Case } \\
\text { study } 8\end{array}$ & $\begin{array}{l}\text { International } \\
\text { Institute for } \\
\text { Industrial } \\
\text { Environmental } \\
\text { Economics (IIIEE) } \\
\text { at Lund University }\end{array}$ & $\begin{array}{l}\text { Developing } \\
\text { countries }\end{array}$ & $\begin{array}{l}\text { Building } \\
\text { energy } \\
\text { efficiency }\end{array}$ & $\begin{array}{l}\text { - A fragmented and } \\
\text { complex construction } \\
\text { process, with an inherent } \\
\text { split incentives dilemma: } \\
\text { Building markets prefer } \\
\text { low initial costs, and get } \\
\text { no benefits from life cycle } \\
\text { energy savings, whereas } \\
\text { users may be willing to } \\
\text { pay a high upfront cost if } \\
\text { significant economic } \\
\text { benefits are possible } \\
\text { during the use phase. (p. } \\
\text { 92) } \\
\text { - Uncertain energy } \\
\text { savings from equipment } \\
\text { due to the influence of } \\
\text { users behavior. (p.92) } \\
\text { - A lack of formal training } \\
\text { and capacity building } \\
\text { among construction } \\
\text { workers makes it difficult } \\
\text { to introduce new } \\
\text { techniques and } \\
\text { innovation in } \\
\text { construction work. (p.93) } \\
\text { - Lack of awareness of } \\
\text { the potential and }\end{array}$ & $\begin{array}{l}\text { - High initial costs for } \\
\text { energy efficient and } \\
\text { renewable energy } \\
\text { equipment. This } \\
\text { means that payback } \\
\text { periods are long (up } \\
\text { to } 30 \text { years) for many } \\
\text { investments. (p.92) } \\
\text { - The limited } \\
\text { importance of energy } \\
\text { expenditures as } \\
\text { compared other } \\
\text { household } \\
\text { improvement or } \\
\text { financial concerns. ( } p \text {. } \\
\text { 92) }\end{array}$ & $\begin{array}{l}\text { - A lack of awareness and } \\
\text { information of the } \\
\text { opportunities, technologies } \\
\text { and low cost of installing } \\
\text { energy saving features. (p.92) } \\
\text { - The lack of government } \\
\text { interest in energy efficiency } \\
\text { and renewable energy, and } \\
\text { insufficient enforcement of } \\
\text { existing policies also present } \\
\text { barriers to energy saving in the } \\
\text { building sector. } \\
\text { - Poor enforcement of building } \\
\text { codes and other mandatory } \\
\text { standards, even among front- } \\
\text { runner countries. (p.92) } \\
\text { - Poor market surveillance } \\
\text { and/or certification measures } \\
\text { mean that low- quality } \\
\text { products can enter the market } \\
\text { and destroy consumer } \\
\text { confidence in the technology. } \\
\text { - Building codes tend to be less } \\
\text { effective, due to insufficient } \\
\text { implementation and } \\
\text { enforcement, and corruption } f \\
\text { or instance, in China the } \\
\text { compliance rate is much higher }\end{array}$ \\
\hline
\end{tabular}


What Are the Roles of National and International Institutions to Overcome Barriers in Diffusing Clean Energy ...

\begin{tabular}{|c|c|c|c|c|c|c|}
\hline \multirow{2}{*}{\multicolumn{2}{|c|}{$\begin{array}{c}\text { Research } \\
\text { organizations/ } \\
\text { individuals }\end{array}$}} & \multicolumn{2}{|c|}{ Information on case study } & \multicolumn{3}{|c|}{ Barriers } \\
\hline & & Country & Technology & Technological barriers & Financial barriers & Institutional barriers \\
\hline & & & & importance of energy & & in large cities than in rural \\
\hline & & & & efficiency measures, lack & & areas.(p.93) \\
\hline & & & & of financing, and lack of & & - Adaption to the local \\
\hline & & & & qualified personnel (p.92) & & situation is crucial, not least for \\
\hline & & & & - Mandatory energy & & utility demand-side \\
\hline & & & & audits and similar tools & & management (DSM) programs, \\
\hline & & & & require training of & & and projects should be \\
\hline & & & & auditors, however, there & & designed to fit the local \\
\hline & & & & is often a lack of & & situation.(p.93) \\
\hline & & & & monitoring of quality of & & \\
\hline & & & & audits.(p.93) & & \\
\hline & & & & - Lack of evaluation and & & \\
\hline & & & & follow-up is a major & & \\
\hline & & & & concern.(p.93) & & \\
\hline \multirow{13}{*}{$\begin{array}{l}\text { Case } \\
\text { study } 9\end{array}$} & United Nations & China & Wind power & & & - Notably, the Chinese \\
\hline & Depertment of & & & & & Government is considering the \\
\hline & Economic and & & & & & implementation of local IP \\
\hline & Social Affairs & & & & & requirements for wind power \\
\hline & (DESA) & & & & & in an attempt to push \\
\hline & & & & & & international companies to \\
\hline & & & & & & transfer more technology. Such \\
\hline & & & & & & stipulations on IP requirements \\
\hline & & & & & & could be contested by \\
\hline & & & & & & international companies under \\
\hline & & & & & & the World Trade Organization \\
\hline & & & & & & or by simply limiting new FDI in \\
\hline & & & & & & this sector. (p.30) \\
\hline \multirow{2}{*}{$\begin{array}{l}\text { Case } \\
\text { study }\end{array}$} & Lewis J. & India and & Wind power & - It took China and India & & - Both China and India have \\
\hline & & China & & less than 10 years to go & & excellent wind resources and \\
\hline \multirow[t]{10}{*}{10} & & & & from having companies & & aggressive, long-term \\
\hline & & & & with no wind turbine & & government commitments to \\
\hline & & & & manufacturing & & promote wind energy \\
\hline & & & & experience to companies & & development...Some of the \\
\hline & & & & capable of & & early support mechanisms in \\
\hline & & & & manufacturing complete & & China and India, in particular, \\
\hline & & & & wind turbine systems, & & led to market instability as \\
\hline & & & & with almost all & & developers were faced with \\
\hline & & & & components produced & & regulatory uncertainty, \\
\hline & & & & locally. This was done & & especially concerning pricing \\
\hline
\end{tabular}




\begin{tabular}{|c|c|c|c|c|c|}
\hline \multirow{2}{*}{$\begin{array}{c}\text { Research } \\
\text { organizations/ } \\
\text { individuals }\end{array}$} & \multicolumn{2}{|c|}{ Information on case study } & \multicolumn{3}{|c|}{ Barriers } \\
\hline & Country & Technology & Technological barriers & Financial barriers & Institutional barriers \\
\hline & & & within the constraints of & & structures for wind power. In \\
\hline & & & national and & & the early years of wind \\
\hline & & & international intellectual & & development in China and \\
\hline & & & property law, and & & India, difficulties also resulted \\
\hline & & & primarily through the & & from a lack of good wind \\
\hline & & & acquisition of technology & & resource data, and a lack of \\
\hline & & & licenses or via the & & information about technology \\
\hline & & & purchasing of smaller & & performance stemming from \\
\hline & & & wind technology & & little or no national \\
\hline & & & companies. While both & & certification and testing. \\
\hline & & & companies pursued & & - Policy reforms in the electric \\
\hline & & & similar licensing & & power sectors of both \\
\hline & & & arrangements to acquire & & countries... has led to a series \\
\hline & & & basic technical & & of regional renewable energy \\
\hline & & & knowledge, Goldwind's & & development targets in India, \\
\hline & & & technology development & & national targets in China, and \\
\hline & & & model lacks Suzlon's & & additional financial support \\
\hline & & & network of strategically & & mechanisms for wind in \\
\hline & & & positioned global & & particular. There are two key \\
\hline & & & subsidiaries contributing & & differences in the policy \\
\hline & & & to its base of industry & & support mechanisms currently \\
\hline & & & knowledge and technical & & used in China and India: (1) \\
\hline & & & capacity. & & China's recent reliance on local \\
\hline & & & - Suzlon's growth model & & content requirements to \\
\hline & & & particularly highlights an & & encourage locally sourced \\
\hline & & & increasingly popular & & wind turbines, which does not \\
\hline & & & model of innovation & & exist in India, and (2) India's \\
\hline & & & practices for & & use of a fixed tariff price for \\
\hline & & & transnational firms...Its & & wind power, versus China's \\
\hline & & & expansive international & & reliance on competitive \\
\hline & & & innovation networks & & bidding to set the price for \\
\hline & & & allow it to stay abreast of & & most of its wind projects. (B) \\
\hline & & & wind technology & & \\
\hline & & & innovations around the & & \\
\hline & & & world so that it can then & & \\
\hline & & & incorporate into its own & & \\
\hline & & & designs through its & & \\
\hline & & & extensive research and & & \\
\hline & & & development facilities. (B) & & \\
\hline
\end{tabular}


What Are the Roles of National and International Institutions to Overcome Barriers in Diffusing Clean Energy ...

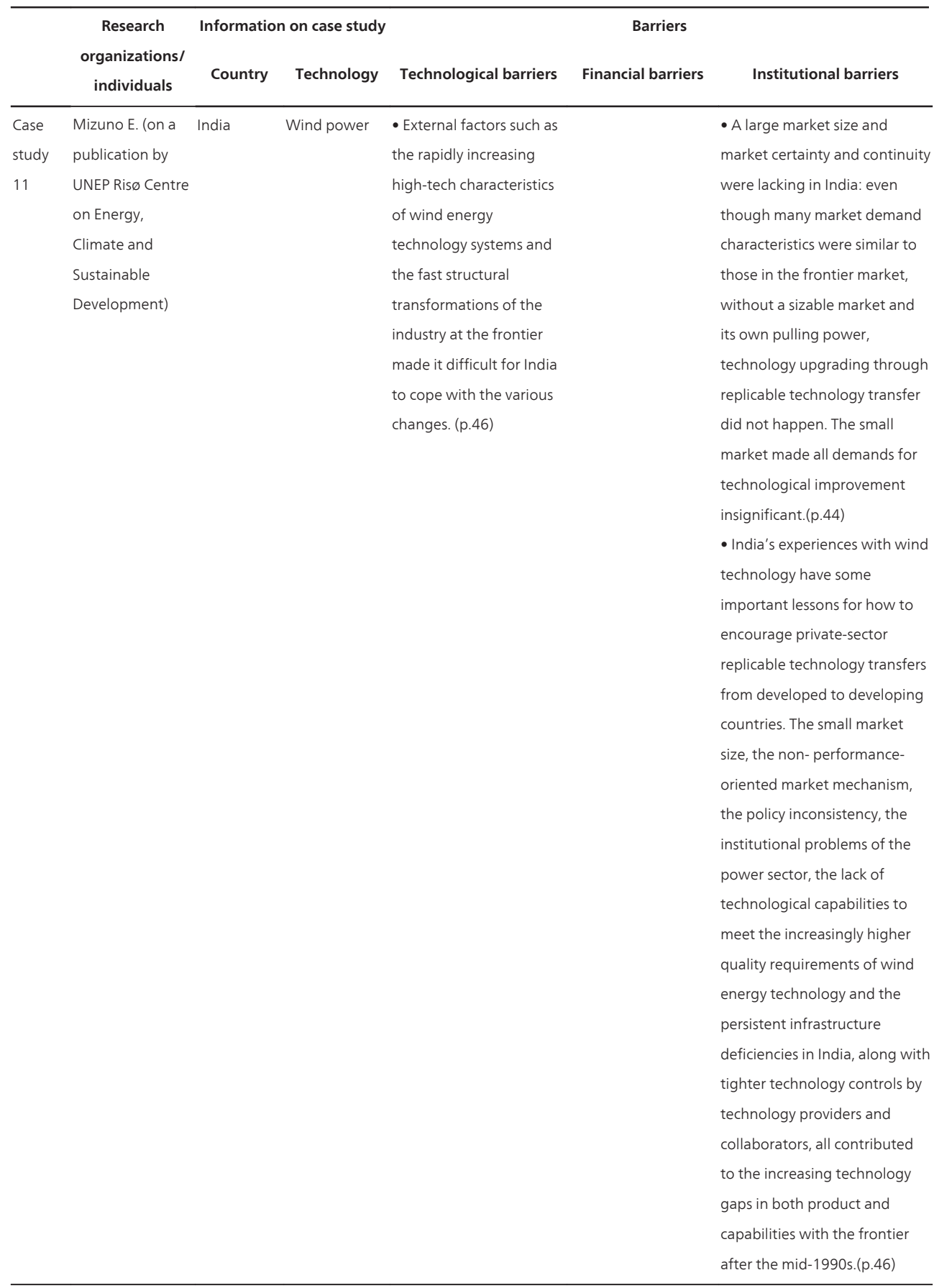




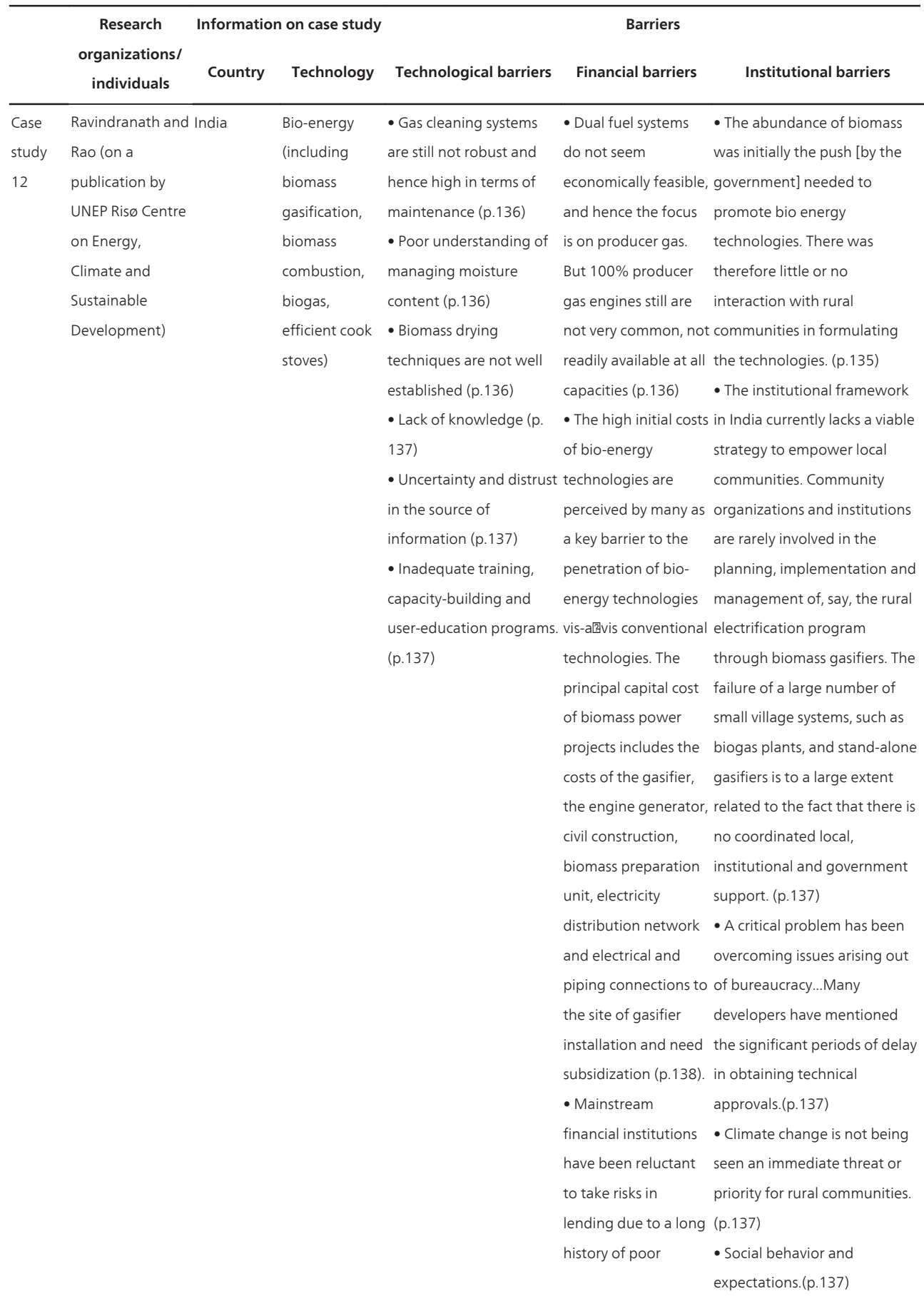




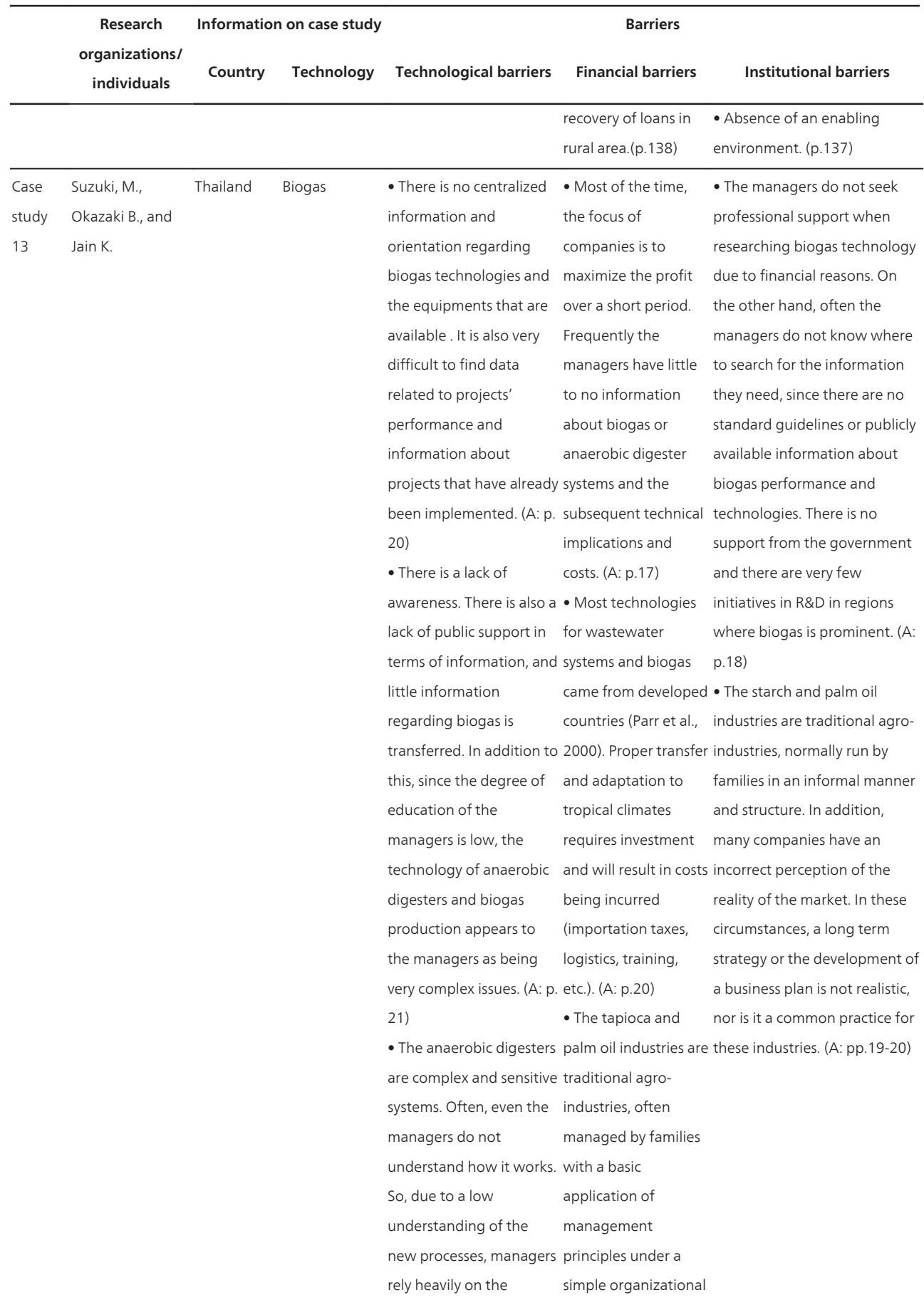




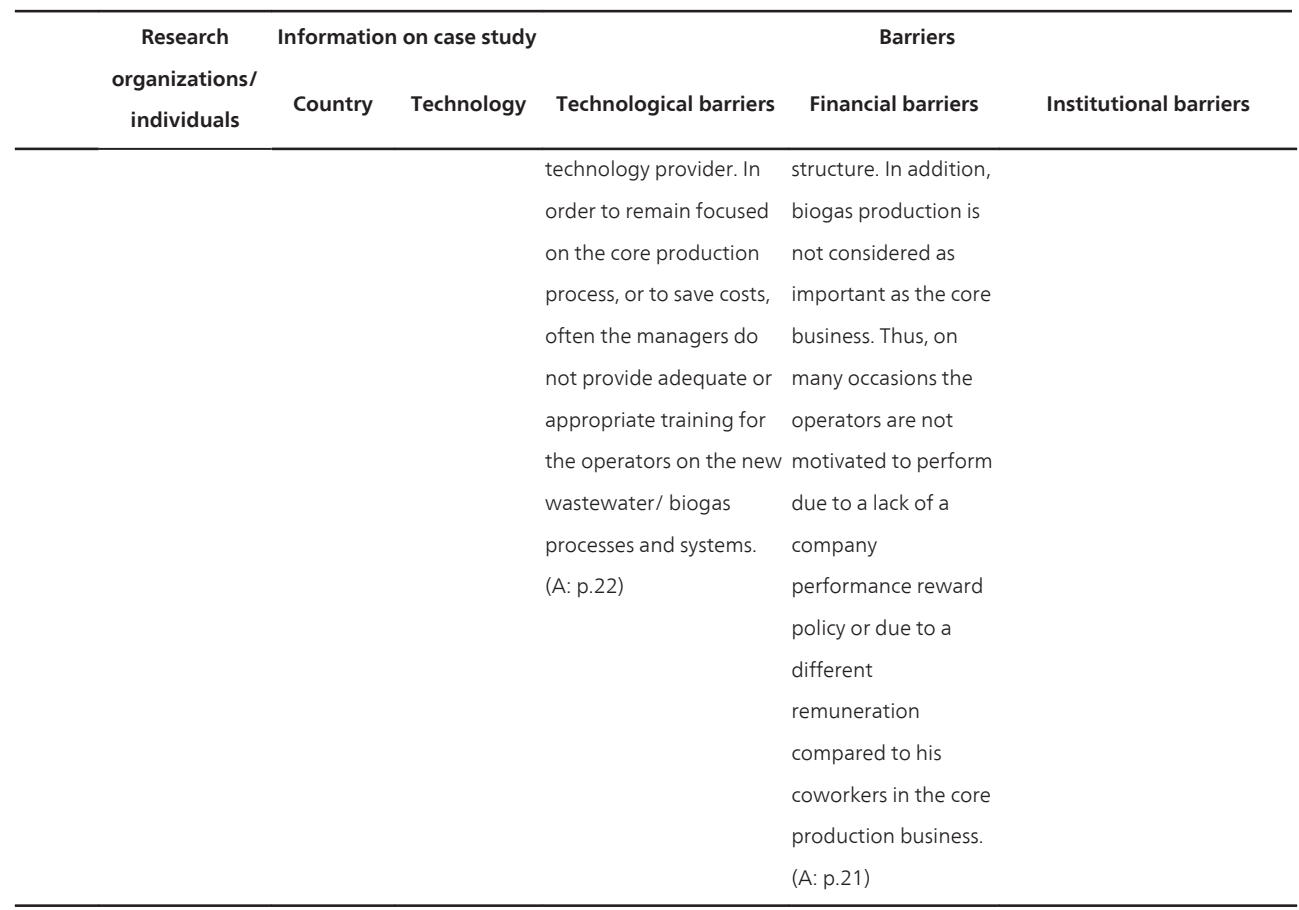

Table 3. Results of case studies

\subsubsection{Barriers for technologies for industrial use: Wind, bio-energy, and energy efficient building}

Starting from wind power, the results of Case Study 1 and 11 suggest that there are institutional and technological barriers for diffusion in India and China. According to Case Study 1, the cost of IPR acquisition is a major barrier in India. Case Study 1 points out that "the [Indian] companies had to depend on their European counterparts for all technical aspects and even operation and maintenance issues." Case Study 11 addresses a similar view that technologically, the wind power in India still hinges upon the external development of the industry. It states that "external factors such as the rapidly increasing high-tech characteristics of wind energy technology systems and the fast structural transformations of the industry at the frontier made it difficult for India to cope with the various changes." On the other hand, Case Study 10 provides a positive evaluation on the development of local wind power production in India and China. It observes that "it took China and India less than 10 years to go from having companies with no wind turbine manufacturing experience to companies capable of manufacturing complete wind turbine systems, with almost all components produced locally." The results of these case studies on wind in India and China indicate that although there is a great level of success in producing indigenous local power technologies, there are still technological as well as institutional barriers for further diffusion in these countries. 
Bio-energy is similar with wind power with respect to its successful implementation in the developing countries. On the other hand, the results of the case studies on bio-energy suggest that it faces different types of barriers for further diffusion. According to Case Study 12, implementations of bio-energy projects in India have met both technological and institutional barriers in the operational phase such as poor understanding of managing moisture content, lack of knowledge, uncertainty and distrust in the source of information and inadequate training, capacity-building and user education programs. The case study on biogas power generation in Thailand comes to a similar conclusion (Case Study 13). It recognizes the "no centralized information and orientation regarding biogas technologies and the equipments" as well as the lack of understanding and awareness as the major barriers for successful implementation of the technologies. The results of these case studies suggest capacity building and knowledge development play an important role in the successful implementation of bioenergy technologies.

The case study on building energy efficiency also suggests that the technological barriers such as lack of knowledge and awareness as well as the institutional barriers such as lack of information on available technologies are major barriers in this case too (Case Study 8). The results of Case Study 8 highlights, as the technological barriers, uncertain energy savings from equipment due to the influence of users behavior, a lack of formal training and capacity building among construction workers, lack of awareness of the potential and importance of energy efficiency measures, lack of financing, and lack of qualified personnel. In the case of building energy efficiency, lack of institutional support is another area of institutional barrier. It points out the lack of government interest in energy efficiency and renewable energy, and insufficient enforcement of existing policies, poor enforcement of building codes and other mandatory standards as major institutional barriers.

\subsubsection{Barriers for technologies for individual use: Hybrid vehicles, LEDs, and PV}

Other than wind power, there are studies that identify IPRs as a major barrier for technological diffusion. The case study on hybrid vehicles in India is one of them. It indicates that IPRs are the major barrier in this case as well since "IPRs are dominated by a concentrated set of foreign companies" (Case Study 5). It states "all of the companies owning commercially viable hybrid technologies are based in developed countries." The results of the case study on LED also suggest that IPRs are the key barrier for the diffusion of LED (Case Study 3). They case study demonstrates that "it is a highly protected technology. As there are various processes involved in manufacturing LED chips, each process is patented and requires huge investment. At present the cost of investing in both chip manufacturing and resolving the IPR issues is substantially high compared to importing the chips." In this regard, there may be important lessons to learn from the previously mentioned case on wind power for producing local technologies despite the existence of IPRs-related barriers. In the case of LED, however, the results of the study indicate there is a separate key barrier for the diffusion of the technology in India. The case study identifies the size of the market as a major financial barrier for technology diffusion in India. It states that there is "no clear indication about the type of market that exists for LED." Furthermore, it stresses that "the leading players worldwide are not 
considering India as a potential region for investment as they do not see any market in India at present."

Interestingly, in contrast to hybrid vehicles and LEDs, the results of the case study on PV in India suggest that IPRs are not an essential barrier for the diffusion of the technology in India (Case Study 6). It maintains that mature production technology for silicon cells is available on the market without licenses since related patents have expired. Moreover, an increasing number of Indian firms are planning on producing the entire PV value chain and are expanding into other areas, such as thin film technology.

\subsubsection{Barriers for technologies at the innovation stage: IGCC and CCS}

The results of the case studies on IGCC and CCS indicate that technological barriers are dominant for technologies at the innovation stage (Case Study 2 and 7). Financial and institutional barriers are not relevant for the technologies at the innovation stage. As for CCS, Case Study 7 states "As CCS is not market mature and does not have any commercial examples in operation, this report cannot address CCS system transfer." As for IGCC, Case Study 2 states "It might be premature to comment on IPR issues related to IGCC, since this technology is not considered to be commercial globally".

Thus far, Section 2.3 discussed technology-specific barriers. Another barrier, which this paper could not address this time, are country-specific barriers. It is recognized that in order to design proper policy instruments and institutions, understanding of barriers that are specific to a certain country or region is equally important. With this regard, Case study 10 is an exception among the selected case studies in highlighting several differences between India and China as to how these two countries overcome barriers to diffuse wind power technologies. It demonstrates that "there are two key differences in the policy support mechanisms currently used in China and India; 1) China's recent reliance on local content requirements to encourage locally sourced wind turbines, which does not exist in India; and 2) India's use of a fixed tariff price for wind power, versus China's reliance on competitive bidding to set the price for most of its wind projects." In addition, it discusses key differences on corporate strategies between two Chinese and Indian wind turbine manufacturing firms. This type of comparative studies are much needed in order for us to have better understanding of barriers in the diffusion of clean energy technologies.

\section{Roles of institutions to overcome identified barriers in diffusing clear energy technologies in Asia}

Section 2 presented the barriers commonly observed in the developing countries as well as the technology-specific barriers. Section 3 explores roles of institutions to overcome these barriers in diffusing clear energy technologies in Asia. Section 3.1 addresses theoretical discussions on the functions of international and national institutions in technology innovation. Section 3.2 attempts to match the barriers in technology diffusion identified in Section 2 with the functions of national and international institutions. 


\subsection{Theoretical discussions on the functions of international and national institutions in technology diffusion}

There are theoretical explorations about the roles of institutions in changing a system in the area of innovation economics and innovation theory. For Joseph Schumpeter, who is the patron of innovation economics, an evolving institution is an important factor for economic growth. Inspired by Schumpeter, scholars in innovation theory attempt to define functions or roles of institutions in changing a system. Borrás, for example, defines that they are 1) competencebuilding and generation of incentives including production of knowledge, diffusion of knowledge, financial innovation, alignment of actors, guidance of innovators; 2) generation of incentives and reduction of uncertainty including appropriation of knowledge, reduction of technological diversity; and 3) establishment of limits and reduction of uncertainty including reduction of risk and control of knowledge usage (Borrás 2004). Another example is a study by Suurs and Hekkert. According to Suurs and Hekkert, there are seven functions of institutions including 1) entrepreneurial activities; 2) knowledge development; 3) knowledge diffusion; 4) guidance of the search; 5) market formation; 6) resource mobilization; and 7) legitimization (Suurs and Hekkert 2009).

There are also research initiatives that attempt to understand the roles of institutions in diffusing clean energy technologies both at the national and international level, although the focus of research is geared toward the national level rather than the international level. At the international level, a study conducted by de Coninck et al. is an example of such research (de Coninck et al. 2008). This study classifies technology-oriented agreements (TOAs) addressing climate change into four broad categories including 1) knowledge sharing and coordination; 2) research, development and demonstration (RD\&D); 3) technology transfer; and 4) technology deployment mandates, standards, and incentives (de Coninck et al. 2008). According to a more recent study by Benioff et al., there are three roles of international institutions for innovation and transfer of clean energy technologies including research, development, and demonstration (RD\&D) cooperation, enhancement of enabling environment, and financing facilitation and support (Benioff et al. 2010).

It is important to note here that the roles of institutions differ along the technological development of clean energy technologies. At the early stages of technological development, institutional support for the empowerment of research groups is needed to demonstrate and deploy technologies (Suzuki 2012). As the case studies on CCS and IGCC indicated in Section 2 , the technologies at the innovation stage require strong $R \& D$ efforts to remove technological barriers in order to move forward to the next stage. At the innovation stage, the empowerment of network between international and local research groups is needed to enhance the R\&D efforts, especially with a stronger initiative from the public side (Benioff et al. 2010; Morey et al. 2011; UNFCCC 2009).

At the advanced stages of technological development, institutional support as well as policy arrangement for the involvement of the actors in the private sector such as project developers, equity investors, manufactures, and commercial banks is essential in technology diffusion 
(GtripleC 2010; Carmody et al. 2007). Providing economic incentives for the private sector are an important measure to improve investment conditions and encourage its participations. Therefore, clean energy and carbon finance vehicles may be also effective to introduce technologies at the advanced stage. For example, the economic policy instruments such as CDM may take an instrumental role. If they are designed well, the schemes under discussion for the post-Kyoto regime such as the bilateral carbon crediting mechanism and the sectoral or program-based crediting mechanism can be also a good policy candidate for technology diffusion. At the national level, an introduction of a feed-in-tariff program has received greater attentions among the developing countries, while other economic instruments such as subsidy, emissions trading, and renewable energy certificate scheme can be also recognized as possible policy options. The investment schemes such as co-investments and loans or risk guarantees may help to reduce risk associated with investment from the private sector (Suzuki 2012). In addition, such an arrangement for building a partnership between the private and the public (Public-Private Partnership: PPP) may leverage the interests of the private sector in developing technologies that would not be attracted to clean energy technologies otherwise.

\subsection{Matching the barriers in technology diffusion with the functions of national and international institutions}

Section 2.3 illustrated technology-specific barriers among different technologies. Section 3.2 attempts to match those barriers with the functions of national and international institutions that were identified in Section 3.1.

The case studies on wind as well as on hybrid vehicles and LED indicated that difficulties associated with IPRs are major barriers in technology diffusions. Indeed, IPRs are complex issues and providing opportunities to learn about the issues can be an important institutional arrangement as the first step. Ockwell, D., J. Watson et al. (2009), on the case of wind in India, states that "there was a need to create awareness among the industry players who do not have deeper understanding of implications of IPR rules and regulations, including those in the context of WTO regime." Preparing patent pools for licensing inventions is often discussed as a necessary arrangement in diffusing clean energy technologies but it requires careful institutional design not to remove incentives for the private sector and discourage its innovational efforts. At the international level, the World Intellectual Property Organization (WIPO) can facilitate such venues for the private sector in the developing countries to learn about IPRsrelated issues.

The case study on LED identified the size of the market as a major barrier. This case, together with the case on building energy efficiency, also pointed out high capital cost as a major barrier. In order to overcome these barriers, the roles of institutions in facilitating and supporting finance are important. On LED, Ockwell, D., J. Watson et al. (2007) states that "as government is already promoting PV integrated energy efficient lighting systems for rural lighting applications, incentives could be provided for LED based PV integrated systems." As for the case on biomass, low priority in finance is recognized as a major barrier. In this case, knowledge 
sharing and coordination is the key in overcoming the barrier in technology diffusion. At this point, Ockwell, D., J. Watson et al. (2007) demonstrates that "all the briquetting machine manufacturers felt that there is practically no collaboration or communication among them. The lack of networking and information sharing among the manufacturers is one of the greatest constraints to diffusion of technological developments in the sector. Hence projects aimed at promoting knowledge sharing among the manufacturers and users of biomass briquettes will be very useful for the sector".

The case studies on bio-energy, biomass, and building energy efficiency all emphasized that lack of the enabling environment is the key barrier in technology diffusion. The case study on bio-energy in India highlighted "poor understanding of managing moisture content, lack of knowledge, uncertainty and distrust in the source of information and inadequate training, capacity-building and user education program" as a major hindrance. The case study on biomass in Thailand pointed out a lack of formal training and capacity building among construction workers, lack of awareness of the potential and importance of energy efficiency measures, lack of financing, and lack of qualified personnel. In order to overcome these barriers associated with a lack of the enabling environment, the case study on bio-energy in India suggested promoting collaboration between industry and academia, for field demonstrations, and promoting feedback and communication between developers and implementers (Ravindranath and Rao 2011). It stated that "the development of training schemes could provide a route to alleviating this skill shortage. It is important to ensure that all staff involved in training and development have been adequately trained themselves. Use of $R \& D$ institutions in training could be beneficial"' (Ravindranath and Rao 2011).

As for the technologies at the early stage of technological development, the cooperation in $R \& D$ between the pubic and the private sectors as well as the cooperation between local and overseas actors are inevitable in order to overcome technological barriers. As emphasized earlier, the strong initiatives from the public side are needed since it is difficult to expect the private sector to play an important role if the business model is not yet visible. The case study on CCS indicated that "given current policy and market conditions, carbon markets appear marginal or inadequate for CCS applications such as industrial-scale demonstration plants to be economically viable without (potentially significant) additional support" (Dalhammar, C. et al. 2009). The case study on IGCC concluded that "one possible approach to overcoming the risks of high capital costs is for government to share the funding of demonstration activities with industry... Financial support from developed to developing countries would be needed to provide for incremental costs and technology transfer fees, through international financing mechanism" (Ockwell, D., J. Watson et al. 2007; Ockwell, D., J. Watson et al. 2009).

Table 4 illustrates both identified barriers and roles of institutions to overcome the identified barriers 


\begin{tabular}{|c|c|c|}
\hline & Early stage & Advanced stage \\
\hline Barriers & $\begin{array}{l}\text { - Technological barriers: Case Study } 2 \text { (IGCC), } 7 \\
\text { (CCS) } \\
\text { - High capital cost: Case Study } 2 \text { (IGCC) }\end{array}$ & $\begin{array}{l}\text { - IPRs: Case Study } 1 \text { (wind), } 9 \text { (wind), } 11 \text { (wind), } 5 \\
\text { (hybrid vehicles), and } 3 \text { (LED) } \\
\text { - Market size: Case study } 3 \text { (LED) } \\
\text { - High capital cost: Case study } 3 \text { (LED), } 8 \text { (building } \\
\text { energy efficiency) } \\
\text { - Low priority in finance: Case Study } 4 \text { (biomass) } \\
\text { - Lack of enabling environment: Case Study } 8 \\
\text { (building energy efficiency), } 12 \text { (bio-energy), } 13 \\
\text { (biogas) } \\
\text { - Lack of policy support: Case Study } 6 \text { (PV), } 8 \\
\text { (building energy efficiency) }\end{array}$ \\
\hline \multirow[t]{3}{*}{$\begin{array}{l}\text { Roles } \\
\text { institutions }\end{array}$} & $\begin{array}{l}\text { In theory... } \\
\text { - R\&D cooperation } \\
\text { - Financing facilitation and support ("resource } \\
\text { mobilization" and "market formation") } \\
\text { - Entrepreneurial activities }\end{array}$ & $\begin{array}{l}\text { In theory... } \\
\text { - Knowledge sharing and coordination (including } \\
\text { "guidance of the search") } \\
\text { - Enhancement of enabling environment } \\
\text { (including "legitimization") } \\
\text { - Financing facilitation and support (including } \\
\text { "market formation" and "resource mobilization") }\end{array}$ \\
\hline & Identified roles & Identified roles \\
\hline & $\begin{array}{l}\text { R\&D cooperation } \\
\text { - Public-supported centers for technology } \\
\text { innovation and transfer. } \\
\text { - Strengthening bilateral and multilateral } \\
\text { network for R\&D. } \\
\text { Financing facilitation and support } \\
\text { - Technology funding mechanisms for the } \\
\text { developing country participants in R\&D. } \\
\text { - Global clean technology venture capital fund. } \\
\text { Entrepreneurial activities } \\
\text { - Clean energy incubator incentives. }\end{array}$ & $\begin{array}{l}\text { Knowledge sharing and coordination/ } \\
\text { enhancement of enabling environment } \\
\text { - Patent pools for licensing inventions. } \\
\text { - Various capacity building programs covering a } \\
\text { whole supply-chain. } \\
\text { - Business matching venues among various } \\
\text { business actors such as project developers, } \\
\text { manufacturers and investors (local and } \\
\text { international). } \\
\text { Financing facilitation and support } \\
\text { - Various clean energy finance and carbon } \\
\text { finance vehicles including CDM, bilateral crediting } \\
\text { scheme, co-benefit approach at the int'l level, } \\
\text { feed-in-tariff, subsidy at the national level. } \\
\text { - Co-investments, loans or risk guarantees. } \\
\text { - Public-Private Partnerships (PPPs). }\end{array}$ \\
\hline
\end{tabular}

Table 4. Identified barriers and roles of institutions to overcome the identified barriers 


\title{
4. Conclusion
}

This paper consisted of two parts. The first part of the paper attempted to show a broad landscape of barriers in technology diffusion in the developing countries by addressing two levels of barriers: generic barriers and technology-specific barriers (Section 1 and 2). Section 2.3 summarized the results of previous case studies that were conducted to uncover technology-specific barriers in diffusing clean energy technologies in Asia.

The second part of the paper explored roles of institutions to overcome the identified barriers in diffusing clear energy technologies in Asia (Section 3). It attempted to match the barriers in technology diffusion identified in Section 2 with functions of national and international institutions. The results of matching indicated that there are several different roles of institutions including the role to encourage R\&D cooperation from the public site for the technologies at the early stages of technological development and the role to enhance the enabling environment and facilitate finance for the technologies at the advanced stages of technological development.

It is recognized that the existing institutions both at the national and international levels have already been working to overcome barriers in diffusing clean energy technologies. For example, at the national level, the governments in the developing countries are conducting various capacity building programs to enhance knowledge of the private sector about clean energy technologies. At the international level, the financial institutions such as the World Bank and Asian Development Bank are facilitating financial support to encourage diffusion of clean energy technologies. At the innovation stage, there are both bilateral (such as the Global CCS Institute for building a network between Australia and the developing countries) and multilateral (such as the Asia-Pacific Partnership on Clean Development and Climate concluded in April 2011) network to encourage technology innovation. Further research is needed to investigate whether these existing institutions are playing a role in overcoming the barriers that were illustrated in this paper.

\section{Acknowledgements}

This work was supported by the Global Environment Research Fund of the Ministry of the Environment, Japan (S-6-3). The author wishes to thank for the support.

\section{Author details}

\author{
Masachika Suzuki*
}

Address all correspondence to: msuzuki@kansai-u.ac.jp

Faculty of Commerce, Kansai University, Suita-shi, Osaka, Japan 


\section{References}

[1] Benioff, R., de Coninck, H., et al. (2010) Strengthening Clean Energy Technology Cooperation under the UNFCCC: Steps toward Implementation, National Renewable Energy Laboratory.

[2] Borrás, S. (2004) System of innovation theory and the European Union, Science and Public Policy, Volume 31, Number 6, 425-433.

[3] Carmody, J. et al. (2007) Investing in Clean Energy and Low Carbon Alternatives in Asia, Asian Development Bank.

[4] Dalhammar, C., P. Peck, N. Tojo, L. Mundaca, and L. Neij (2009) Advancing Technology Transfer for Climate Change Mitigation: Considerations for Technology Orientated Agreements Promoting Energy Efficiency and Carbon Capture and Storage (CCS), IIIEE Report.

[5] de Coninck, H. et al. (2008) International technology-oriented agreements to address climate change, Energy Policy 36(1).

[6] Doukas, H., C. Karakosta and J. Psarras (2009) RES technology transfer within the new climate regime: a "helicopter" view under the CDM, Renewable and Sustainable Energy Reviews, 13: 1138-1143.

[7] Flamos, A., W. Van der Gaast, H. Doukas, and G. Deng (2008) EU and Asian countries policies and programmes for the diffusion of sustainable energy technologies, Asia Europe Journal, 6(2): 261-276.

[8] GtripleC (2010) Engaging Private Sector Capital at Scale in Financing Low Carbon Infrastructure in Developing Countries, Asian Development Bank.

[9] Guerin, T. F. (2001) Transferring environmental technologies to China recent developments and constraints, Technol Forecast Soc Change, 67: 55-75.

[10] IPCC (2001) Methodological and Technological Issues in Technology Transfer, New York: Cambridge University Press.

[11] Jagadeesh, A. (2000) Wind energy development in Tamil Nabu and Andhra Pradesh, India Institutional dynamics and barriers-A case study, Energy Policy 28:157-168.

[12] Jain, K., Okazaki. B., and Suzuki, M. (2011) Challenges and Barriers in Technology Transfer and Performance of Biogas Plants in Southeast Asia. An Analysis of Tapioca and Palm Oil Industries Associated with CDM Business in Thailand, Working paper for IMRE Alumni Conference 2011, Institute of Technology Bandung, Indonesia.

[13] Karakosta, C., H. Doukas and J. Psarras (2010) Technology transfer through climate change: setting a sustainable energy pattern, Renewable and Sustainable Energy Reviews, 14: 1546-1557. 
[14] Lewis, J., (2007) A Comparison of Wind Power Industry Development Strategies in Spain, India and China, Prepared for the Center for Resource Solutions.

[15] Lewis, J., (2007) Technology acquisition and innovation in the developing world: wind turbine Development in China and India. Studies in Comparative International Development, 42.3-4.

[16] Luken, R. and F. Van Rompaey (2008) Drivers for and barriers to environmentally sound technology adoption by manufacturing plants in nine developing countries, Journal of Cleaner Production, 16(S1): 67-77.

[17] Morey, J. et al. (2011) Moving Climate Innovation into the 21st Century: Emerging Lessons from Other Sectors and Options for a New Climate Innovation Initiative, Clean Energy Group.

[18] Ockwell, D., J. Watson, G. MacKerron, P. Pal, F. Yamin, N. Vasudevan, and P. Mohanty (2007) UK-India Collaboration to Identify Barriers to the Transfer of Low Carbon Energy Technology: Final Report.

[19] Ockwell, D., J. Watson, G. MacKerron, P. Pal, F. Yamin, N. Vasudevan, and P. Mohanty (2009) UK-India Collaborative Study on the Transfer of Low Carbon Technology: Phase II Final Report.

[20] OECD/IEA (2001) Technology without Borders: Case Studies of Successful Technology Transfer, OECD/IEA, Paris.

[21] Painuly, J. (2001) Barriers to renewable energy penetration; a framework for analysis, Renewable Energy, 24(1), 73-89.

[22] Painuly, J. and J. V. Fenhann (2002) Implementation of Renewable Energy Technologies - Opportunities and Barriers, UNEP Collaborating Centre on Energy and Environment, Risø National Laboratory, Roskilde.

[23] Ravindranath, N. H. and Blachndra (2009) Sustainable bioenergy for India: Technical, economic and policy analysis, Renewable Energy, 34, pp.1003-1013.

[24] Reddy, S. and J. P. Painuly (2004) Diffusion of renewable energy technologies-barriers and stakeholders' perspectives, Renewable Energy, 29, pp.1431-1447.

[25] Schneider, M., A. Holzer, and V. H. Hoffmann (2008) Understanding the CDM's Contribution to Technology Transfer, Energy Policy, 36: 2930-2938.

[26] Suurs, R., Hekkert, M. (2009) Cumulative causation in the formation of a technological innovation system: The case of biofuels in the Netherlands, Technological Forecasting \& Social Change, 76: 1003 - 1020.

[27] Suzuki, M. (2012) Addressing a Portfolio of Effective Policy Measures and Financial Mechanisms to Encourage Technology Innovation and Transfer of Clean Energy Technologies in the Asia-Pacific Region, International Society for Ecological Economics, Rio de Janeiro, June 18th 2012. 
[28] Suzuki, M., Okazaki B., and Jain K. (2010) Identifying Barriers for the Implementation and the Operation of Biogas Power Generation Projects in Southeast Asia: An Analysis of Clean Development Projects in Thailand, Economics and Management Series Working Paper, EMS-2010-20, International University of Japan.

[29] Thorne, S. (2008) Towards a Framework of Clean Energy Technology Receptivity, Energy Policy, 36: 2831-3838.

[30] UNEP Risø Centre on Energy, Climate and Sustainable Development (2011) Diffusion of Renewable Energy Technologies: Case Studies of Enabling Frameworks in Developing Countries, UNEP Collaborating Centre on Energy and Environment, Risø National Laboratory, Roskilde.

[31] UNFCCC (2003) Enabling Environments for Technology Transfer, Technical Paper, FCCC/TP/2003/2.

[32] UNFCCC (2009) Advance Report on Recommendations on Future Financing Options for Enhancing the Development, Deployment, Diffusion and Transfer of Technologies under the Convention, Note by the Chair of the Expert Group on Technology Transfer, FCCC/SB/2009/ INF.2.

[33] UNFCCC (2011) Report of the Conference of the Parties on its sixteenth session, held in Cancun from 29 November to 10 December 2010, Addendum, Part Two: Action taken by the Conference of the Parties at its Sixteenth Session, FCCC/CP/2010/7/Add. 1.

[34] Usha R.K. and Ravindranath N.H. (2002) Policies to overcome barriers to the spread of bioenergy technologies in India, Energy for Sustainable Development 2002; 6(3): 59-73.

[35] Worrell, E., R. van Berkel, Z. Fengqi, C. Menke, R. Scaeffer, and R. O. Williams (2001) Technology Transfer of Energy Efficient Technologies in Industry: A Review of Trends and Policy Issues, Energy Policy, 29: 29-43. 